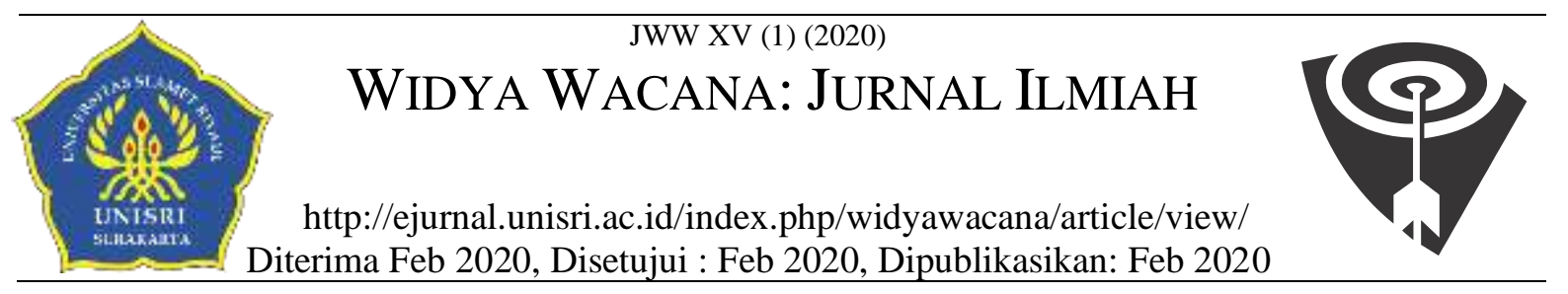

\title{
EFEKTIFITAS PENGGUNAAN APE KETNI SERU (BASKET MINI SERBAGUNA) UNTUK MENINGKATKAN KEMAMPUAN MEMBILANG BENDA 1-10 PADA ANAK USIA 4-5 TAHUN DI RA AL ISLAM 3 GEBANG SURAKARTA TAHUN 2019/2020
}

\author{
Fitri Apqorinur 'Aeni ${ }^{1}$, Lydia Ersta Kusumaningtyas ${ }^{2}$, Paulus Widjanarko ${ }^{3}$ \\ Universitas Slamet Riyadi \\ Email : fitri_nur_aini@yahoo.co.id
}

\begin{abstract}
ABSTRAK
Tujuan penelitian ini adalah Untuk mengetahui peningkatan kemampuan membilang benda 1-10 anak usia 4-5 tahun melalui Alat Permainan Edukatif KETNI SERU (BASKET MINI SERBAGUNA) pada tahun ajaran 2019/2020. Penelitian ini dilaksanakan di RA Al Islam 3 Gebang Surakarta. Subjek dari penelitian ini adalah siswa kelas A2 berjumlah 24 siswa. Penelitian ini adalah penelitian kualitatif yang menggunakan teknik pengumpulan data, validitas data dan teknis analisis data. Teknik pengumpulan data yang digunakan yaitu, observasi, wawancara dan dokumentasi. Metode observasi ini digunakan untuk memperoleh gambaran yang menyeluruh tentang Peningkatan Kemampuan Kognitif Anak Usia 4-5 Tahun Melalui APE KETNI SERU di RA Al Islam. Pada saat melakukan observasi, tentunya ada beberapa hal yang tidak ditemukan oleh peneliti. Oleh karena itu peneliti menggunakan teknik wawancara untuk melengkapi informasi yang ingin didapatkan. Sedangkan teknik dokumentasi, metode ini digunakan untuk memperoleh data yang berkaitan dengan berbagai kegiatan yang mendukung penggunaan APE KETNI SERU dalam meningkatkan membilang benda 1-10 anak. Sedangkan data yang akan dikumpulkan dengan metode dokumentasi meliputi foto-foto kegiatan sekolah, RPPH, dan dokumen tentang hasil evaluasi anak. Penggunaan APE di RA Al Islam 3 Gebang ini dapat dilihat bahwa anak menjadi lebih antusias dan senang belajar membilang benda dengan menggunakan APE KETNI SERU. Anak bisa belajar sambil bergerak. Tidak hanya duduk diam saja mendengarkan guru menjelaskan pembelajaran. Anak menjadi tidak bosan, bahkan berebut ingin mencobanya. APE KETNI SERU memberikan pengalaman belajar yang baru bagi anak. Pembelajaran yang menyenangkan tentunya. APE KETNI SERU (BASKET MINI SERBAGUNA) efektif untuk meningkatkan kemampuan membilang benda 1-10 pada anak usia 4-5 tahun.
\end{abstract}

Kata Kunci : APE Ketni Seru, Membilang benda, Anak Usia Dini

ABSTRACT

The purpose of this study was to study the ability to improve objects 1-10 children aged 4-5 years through the KETNI SERU Educational Tool (BASKET MINI SERBAGUNA) in the 2019/2020 school year. This research was conducted at RA Al Islam 3 Gebang Surakarta. The subjects of this study were A2 class students studying 24 students. This research is a qualitative study using data collection techniques, data validity, and technical data analysis. Data collection techniques used are, observation, interview and documentation. This Observation Method is used to obtain a picture that discusses the Improvement of Cognitive Ability of Children 4-5 Years Old Through APE KETNI SERU in RA Al Islam. When doing observations, do some things that are not found by researchers. Therefore, researchers use interview techniques to complete the information to be obtained. While documentation techniques, this method is used to obtain data related to activities that support the use of APE KETNI SERU in increasing numbers of objects 1-10 children. While the data collected using photographs of school activities, RPPH, and documents about the results of children's evaluations. The use of APE in RA Al Islam 3 Gebang can be seen by children who become more happy and happy to learn to spell things by using APE KETNI SERU. Children can learn while moving. Not just sitting quietly listening to the teacher explain the learning. Children don't get bored, 
sometimes even wanting to argue. APE KETNI SERU provides new learning experiences for children. Learning fun. APE KETNI SERU (BASKET MINI SERBAGUNA) is effective to improve the ability to say 1-10 objects in children aged 4-5 years.

Keywords: APE Ketni Exciting, Counting objects, Early Childhood

\section{PENDAHULUAN}

Kognitif ialah berfikir atau kecerdasan pendapat ini diperoleh dari Soemiarti Patmonodewo (2008: 27). Usaha manusia untuk mendapatkan suatu pengetahuan tentang segala sesuatu di dunia, usaha tersebut melalui suatu proses antara lain belajar, berfikir, memahami, mengingat dan menangkap suatu informasi disebut dengan proses berfikir.

Perkembangan kognitif ialah masa dimana proses berpikir, termasuk mengingat, berpikir kritis yang paling dasar, mulai dari anak-anak, pemuda hingga dewasa. Beberapa cara yang dilaksanakan dalam upaya mengembangkan kognitif, antara lain pembelajaran melalui permainan atau bermain.

Masa emas perkembangan anak usia dini atau lebih dikenal dengan sebutan golden age berada pada usia 0 bulan sampai 6 tahun. Pada masa golden age ini, anak mudah sekali mengingat, menghafal, meniru apapun yang dilihat dan didengar. Oleh sebab itu prinsip pembelajaran yang digunakan haruslah menyenangkan bagi anak. Misalnya, bernyanyi, menari, lomba,bermain dll. Pada dasarnya setiap anak usia dini punya kemampuan, sifat dan keunikan yang berbeda anatar satu anak dengan anak lain.Hal ini dipengaruhi oleh pertumbuhan dan stimulasi yang diberikan.

Pada saat melakukan proses belajar mengajar, guru memerlukan alat permainan edukatif baik tradisional maupun modern untuk mempermudah menjelaskan apa yang akan disampaikan kepada anak. Pembelajaran yang disampaikan oleh guru kepada anak didik dapat tersampaikan dengan baik apalagi hal yang abstrak. Peniliti telah melakukan pengamatan awal di RA Al Islam 3 Gebang, hasilnya peneliti masih menemukan anak dalam kemampuan kognitif khususnya membilang benda 1-10 masih belum memenuhi standar tingkat pencapaian perkembangan anak yang terdapat didalam permendikbud no 137 tahun 2014. Peneliti mendapatkan data dari guru kelas A2, bahwa masih ada 2 anak yang masih kesulitan untuk membilang benda 1-10. Kemampuan kognitif khususnya membilang benda 1-10 dikatakan oleh peneliti masih belum memuaskan diperoleh dari hasil observasi, wawancara dan dokumentasi yang diperoleh peneliti. Terbukti pada saat observasi, ketika guru meminta anak untuk membilang benda yang berjumlah 5 anak malah menyebutkan bilanagan lebih dari 5 dan ada juga kurang dari 5. Selain itu anak juga belum mampu menghubungkan symbol suatu angka. Hal ini terlihat ketika anak diminta oleh guru untuk melingkari angka 7 , yang dilingkari oleh anak adalah angka 4 . Terutama 2 anak keseluruhan siswa dikelas A2. Sangat kesulitan dalam membilang benda $1-10$.

Dari kejadian diatas maka peneliti mencoba menggali apa yang membuat anak belum mampu membilang benda 1-10 dan dari observasi, wawancara dan dokumentasi yang dilakukan peneliti. Maka, diperoleh kesimpulan bahwa guru pada saat pembelajaran menggunakan alat peraga yang sama berulang-ulang bahkan hanya menggunakan jari tangan saja ketika membilang. Setelah menemukan kasus diatas, peneliti mengadakan penelitian dengan judul" Efektifitas Penggunaan APE KETNI SERU (BASKET MINI SERBA GUNA) untuk Meningkatkan Kemampuan Membilang Benda 1-10 pada Anak Usia 4-5 Tahun di RA Al Islam 3 Gebang Surakarta.

\section{Identifikasi Masalah}

Identifikasi masalah ditentukan oleh peneliti setelah membuat latar belakang diatas, dan masalah tersebut adalah sebagai berikut: kemampuan membilang benda anak belum muncul indicator sesuai harapan dan 
pemicunya adalah karena alat peraga yang digunakan guru masih monoton.

\section{Perumusan Masalah}

Rumusan masalah ditentukan oleh peneliti setelah membuat pembatasan masalah diatas, berikut adalah rumusan masalah yang ditentukan: Bagaimana kemampuan membilang benda anak usia 4-5 tahun ? Bagaimana cara penggunaan APE KETNI SERU ?

\section{KAJIAN PUSTAKA}

\section{Kerangka Teori}

\section{Kemampuan Kognitif Anak Usia Dini} Pengertian dari Kemampuan Kognitif Anak Usia Dini

Kognitif ialah berfikir atau kecerdasan pendapat ini diperoleh dari Soemiarti Patmonodewo (2008: 27). Pendapat lainnya menyatakan jika kognitif ialah kemampuan dalam membandingkan, mengenal, memecahkan masalah, mengingat dan kecerdasan menurut Ahmad Susanto (2011:5).

Robert Gagne salah satu diantara sekian pencetus dari teori kognitf. Teori kognitif menganggap bahwa belajar merupakan proses dalam mengolah, mendapatkan, menyimpan, lalu mengingat suatu informasi yang dikendalikan otak. Mengingat suatu kegiatan yang rumit, bukan suatu hal sederhana. Mengingat adalah kemampuan yang ditentukan oleh beberapa hal, antara lain STM, otomatisasai dan organisasi memori. Ketika memori disusun dengan baik pasti mudah diingat, namun kebalikannya jika informasi yang tidak terorganisasi dengan baik pasti akan sulit diingat. Untuk menata memori bisa dilakukan dengan berbagai metode, diantaranya yaitu dengan memperlihatkan sesuatu yang menarik perhatian anak. Oleh sebab itu, pembelajaran di PAUD dianjurkan kegiatan yang menyenangkan, melibatkan berbagai indra, dan menantang. Disimpulkan dari bebrapa pendapat diatas kognitif ialah suatu proses bagi manusia dalam memahami, mengingat, mengetahui, berfikir, dan juga memecahkan suatu permasalahan.

\section{Tahap Perkembangan Kemampuan Kognitif AUD}

Gardner memiliki pendapat, jika anak kemampuan untuk berargumentasinya meningkat dapat dikatakan bahwa kemampuan kognitifnya berkembang (Mansur; 2011:34). Pendapat dari Soemarti Patmonodewo (2008:27) berbunyi ketika anak berfikir untuk sesuatu hal, baik itu untuk menyelesaikan masalah atau menemukan sesuatu yang baru ini sudah berarti ada suatu perkembangan kemampuan kognitif. Kemampuan anak ketika berfikir untuk menyelesaikan suatu permasalahan ataupun menemukan sesuatu yang baru, menjadi tolak ukur perkembangan kemampuan kognitif anak. Maka diambilah kesimpulan bahwa perkembangan kognitif anak adalah kemampuan untuk menyelesaikan suatu permasalahan dengan menggunakan segala sesuatu informasi yang dimiliki atau diterima oleh anak. Dari sekian banyak pakar teori kognitif, peneliti menemukan 1 tokoh yang cukup dikenal di kalangan pendidik PAUD yaitu Jean Piaget. Beliau adalah pakar psikologi dan biologi. Jean Piaget berasal dari Swiss, kehidupannya diwarnai dengan penelitian untuk mengetahui perkembangan kognitif anak. Dari penelitian yang dilakukannya, dia memiliki kesimpulan bahwa perkembangan kognitif dipengaruhi oleh kemandirian, bahasa dan social emosional anak. Piaget didalam bukunya (Masitoh, 2012:2.13) menerangkan 4 tahapan dalam perkembangan kemampuan kognitif anak, yaitu tahap sensorimotor, praoperasional, operasional konkrit, dan formal operasional.

Standar Tingkat Pencapaian Perkembangan Anak (STPPA) Kognitif AUD

\begin{tabular}{|c|c|}
\hline \multicolumn{2}{|c|}{$\begin{array}{c}\text { Standar Tingkat Perkembangan } \\
\text { Kognitif Anak Usia 4-5 Tahun }\end{array}$} \\
\hline $\begin{array}{l}\text { C.Berfikir } \\
\text { Simbolik }\end{array}$ & $\begin{array}{l}\text { 1.Membilang banyak benda } \\
\text { satu sampai sepuluh } \\
\text { 2.Mengenal konsep bilangan } \\
\text { 3.Mengenal lambang } \\
\text { bilangan an lambang huruf } \\
\text { 4.Mengenal }\end{array}$ \\
\hline
\end{tabular}


Faktor-faktor yang Mempengaruhi dalam Perkembangan Kognitif AUD

Ada 3 faktor yang mempengaruhi perkembangan kognitif pada anak menurut Mirroh Fikriyati (2013:57), yaitu;

1) Lingkungan, lingkungan yang didalamnya cukup dengan rangsangan dan kasih sayang, besar kemungkinan kecerdasan anak akan meningkat. Stimulasi yang diperoleh dari lingkungan yang baik akan berimbas pada penambahan jumlah sinaps (penghubung) perneuron (sel saraf), penambahan korteks (lapisan) otak dan penambahan pembuluh kapiler. 2)Kematangan, fungsi dari organ tubuh akan menjadi sempurna jika perkembangan dari susunan saraf-saraf matang selain itu, indra akan lebih berfungsi dengan baik ketika telah matang dengan sempurna. 3) Pengaruh Sosial,di dalam lingkungan social terdapat hubungan timbal balik, contohnya pengasuhan dan pendidikan, hal ini berpengaruh terhadap perkembangan kognitif anak. Anak yang diasuh dengan kasih sayang, kelembutan dan kehangatan pasti perkembangan kognitifnya akan lebih maksimal dibandingkan anak yang diasuh tanpa kasih sayang, kelembutan dan kehangatan.

\section{Alat Permainan Edukatif (APE)}

Pengertian Alat Permainan Edukatif (APE)

APE ada untuk memaksimalkan pembelajaran pada anak. Sehingga pembelajaran lebih menyenangkan dan lebih mudah dipahami oleh anak, selain itu lebih efektif untuk menjelaskan tentang suatu hal yang tidak mudah untuk dipahami oleh anak (Wiyani dan Barnawi, 2014: 149). APE baik berupa tradisional maupun modern, digunakan untuk memaksimalkan perkembangan anak dan merangsang aspek perkembangan anak tanpa disadari oleh anak itu sendiri, pendapat ini menurut Ismail (2009: 141). APE adalah alat permainan yang menghibur namun juga bisa mendidik anak. Melalui APE, pengetahuan anak menjadi meningkat. APE seharusnya sesuai dengan perkembangan anak dan usia anak, Menurut Syamsuardi (2012: 61).
APE memang disiapkan secara khusus untuk keperluan pendidikan anak usia dini. Sugianto dalam Wiyani dan Barnawi (2014: 149) mengatakan bahwa APE berkaitan erat dengan perkembangan untuk anak usia dini dari pernyataan tersebut pengertian APE untuk anak usia dini adalah suatu alat permainan yang diciptakan secara khusus yang memiliki tujuan untuk meningkatkan seluruh aspek perkembangan anak usia dini.

Permainan edukatif merupakan permainan yang mempunyai unsur mendidik yang diperoleh dari sesuatu yang melekat dan ada serta ambil bagian dari permainan itu sendiri. Disamping itu, permainan juga memberi respon positif atau rangsangan terhadap indra pemainnya pernyataan ini menurut Fathul Mujib dan Nailur Rahmawati, (2013:29). Indra yang dimaksud adalah penglihatan, pendengaran, menulis, suara, kesimbangan kognitif, daya pikir, motorik (keseimbangan gerak, daya tahan, kekuatan, keterampilan, dan ketangkasan), kekayaan social serta afeksi dan spiritual (budi pekerti yang luhur, cinta, kasih sayang, etika,kejujuran, tata krama dan sopan santun, persaingan sehat, serta pengorbanan). Keseimbangan dari indra inilah dirancang agar mempengaruhi inajinasi, jasmani,nalar, karakter dan watak, sampai tujuan pendewasaan diri. Sebab, watak dari seseorang menjadi penentu arah perjalanan hidupnya.

Dari pendapat diatas diambil kesimpulan bahwa alat bermain memiliki fungsi menghibur dan mendidik oleh sebab itu tidak bisa dipisahkan dari anak. Maka, Alat Peraga Edukatif merupakan sarana pembelajaran yang mampu merangsang berbagai aktivitas anak dalam mempelajari suatu hal tanpa anak menyadarinya, baik menggunakan teknologi sederhana maupun modern baik bersifat modern maupun bersifat tradisional.

\section{Ciri-ciri Alat Permainan Edukatif (APE)} untuk Anak Usia Dini

Alat Permainan Edukatif untuk Anak Usia Dini, memiliki ciri tersendiri dan harus dipenuhi agar benar-benar menjadi Alat permainan Edukatif untuk anak usia dini. Suatu Alat Permainan apabila telah memenuhi 
ciri-ciri yang telah ditentukan tersebut, maka sudah bisa digunakan dan diberikan untuk anak usia dini pendapat ini dikemukakan oleh Wiyani dan Barnawi (2014: 150-151). Ciri-ciri tersebut adalah sebagai berikut: Berfungsi mengembangkan aspek-aspek perkembangan anak usia dini, dapat dipergunakan melalui beberapa cara dan mampu mengembangkan aspek perkembangan serta bermanfaat multiguna, untuk anak usia dini, aman bagi anak, untuk memotivasi anak agar menuju kearah positif, Ada nilai-nilai pendidikan yang terkandung didalamnya, Mampu menghasilkan sesuatu atau memiliki sifat konstruktif.

\section{Pengertian Anak Usia Dini}

Anak Usia Dini adalah anak yang sedang mengalami perkembangan dan pertumbuhan pada rentang usia 0 bulan sampai 6 tahun, pendapat ini menurut Barnawi dan Novan Ardy Wiyana (2014: 32). Berbeda lagi pendapat dari Beichler dan Snowman (Dwi Yulianti, 2010: 7), mereka beranggapan bahwa anak usia dini adalah anak yang berusia 3 tahun sampai 6 tahun.

Hakikat dari anak usia dini (Augusta, 2012) adalah anak usia dini merupakan individu yang unik ia memiliki pola perkembangan dan pertumbuhan dalam aspek kognitif, fisik, sosio- emosional, bahasa, kreatifitas dan komunikasi yang khusus yang hanya dialami oleh anak. Sedangkan pendapat lain, anak usia dini (Mulyasa, 2012:20) seseorang yang sedang mengalami lompatan perkembangan yang sangat pesat.

UU NO.20 Tahun 2003 tentang Sistem Pendidikan Nasional Bab 1, pasal 1, butir 14 didalam buku Novan Ardy Wiyana dan Barnawi (2014: 37) berpendapat, bahwa pendidikan anak usia dini ialah suatu usaha membimbing, mengarahkan, mendidik yang diberikan kepada anak berusia 0-6 tahun untuk membantu perkembangan dan pertumbuhan rohani dan jasmani supaya anak siap dalam memasuki pendidikan selanjutnya melalui pemberian rangsangan pendidikan. Menurut Mansur (2011: 88) pendidikan anak usia dini adalah suatu proses tumbuh dan berkembang anak usia 0-6 tahun yang mencakup seluruh aspek perkembangan agar berkembang secara optimal. Menurut Peraturan Pemerintah RI Nomor 27 tahun 1990 dalam buku Mansur (2011: 19), mengatur pendidikan prasekolah, dikatakan jika program kegiatan pembelajaran anak usia dini meliputi berbagai aspek sebagai berikut: disiplin, moral, agama, daya piker, kemampuan bahasa, emosi, daya cipta, kemampuan bermasyarakat, keterampilan, sosial, dan jasmani. UU RI Nomor 2 tahun 1989 pasal 12 ayat 1 dalam buku Soemarti Patmonodewo (2008: 43), pendidikan anak usia dini ialah pendidikan yang diadakan yang memiliki tujuan mengembangkan pengetahuan, kepribadian, dan keterampilan yang menjadai landasan pendidikan dasar dan pengembangan diri sedini mungkin. Melalui penjabaran diatas, diambil kesimpulan bahwa pendidikan anak usia dini adalah suatu usaha dalam bentuk pemberian rangsangan yang tepat untuk menumbuhkan dengan optimal berbagai aspek perkembangan anak, agar anak siap untuk melanjutkan ke jenjang selanjutnya, yaitu SD. Masa kanak-kanak adalah masa saat anak belum mampu mengembangkan potensi yang ada dalam dirinya. Anak cenderung senang bermain pada saat yang bersamaan, inginnya menang sendiri dan seringkali mengubah aturan main untuk kepentingan diri sendiri. Oleh sebab itu, diperlukan upaya pendidikan agar semua aspek perkembangan berkembang optimal, baik perkembangan fisik maupun perkembangan psikis. Potensi anak yang sangat penting untuk dikembangkan. Potensi-potensi tersebut meliputi kognitif, bahasa, sosio- emosional, kemampuan fisik dan lain sebagainya.

\section{METODE PENELITIAN \\ Lokasi Penelitian}

Penelitian ini dilakukan di RA Al Islam 3 Gebang yang berada di Clolo Rt 02 Rw 31 kelurahan Kadipiro kecamatan Banjarsari kota Surakarta. Alasan penelitian ini dilakukan disini karena di RA Al Islam 3 Gebang dalam proses pembelajaran menggunakan APE KETNI SERU. Hal tersebut sesuai dengan tema penelitian yang diangkat peneliti yaitu Efektifitas Penggunaan APE KETNI SERU (BASKET MINI SERBA GUNA) untuk 
Meningkatkan Kemampuan membilang benda 1-10 pada Anak Usia 4-5 Tahun di RA Al Islam 3 Gebang Surakarta. Penggunaan APE KETNI SERU inilah yang menjadi pertimbangan peneliti untuk melakukan penelitian di lokasi tersebut.

\section{Waktu Penelitian}

Penelitian ini sudah dilakukan di RA Al Islam 3 Gebang pada saat memasuki semester genap di Tahun ajaran 2019/2020 dibulan November sampai bulan Januari 2020.

\section{Subyek Penelitian}

Subyek dalam penelitian ini yaitu Ibu Sri Lestari, S.Pd selaku guru kelompok A2 di RA Al Islam 3 Gebang Kadipiro Kota Surakarta Tahun Pelajaran 2019/2020.

\section{Informan Penelitian}

Informan dalam penelitian ini adalah Kepala Sekolah (Ibu Endang Yulianti, S.PdI) dan siswa Kelompok A2 di RA AL Islam 3 Gebang Kadipiro Kota Surakarta Tahun Pelajaran 2019/2020.

\section{Data dan Sumber Data Data Primer}

Data yang langsung diperoleh peneliti di lapangan di sebut dengan data primer (Nasution, 1984: 64). Data ini berupa seluruh tindakan, tingkah laku, perilaku, hasil wawancara yang didapat peneliti pada saat berada di lapangan. Seluruh informasi tentang RA Al Islam 3 Gebang ini, diperoleh dari data primer. Ibu Sri Lestari selaku wali kelas A2 menjadi sumber informasi utama penelitian. Sedangkan ibu Endang selaku kepala sekolah menjadi pelengkap sumber informasi.

\section{Data Sekunder}

Peneliti masih memerlukan data lain yang mungkin tidak didapat dilapangan. Data ini bisa didapatkan dari buku, sumber bacaan lain ataupun dari dokumen milik instansi resmi pemerintah. Dat sekunder ini digunakan untuk lebih menguatkan data yang didapatkan peneliti dari data pprimer yang telah dikumpulkan melalui dokumentasi, observasi, dan wawancara di RA Al Islam 3 Gebang.

\section{Teknik Pengumpulan Data}

Pengumpulan data pada dasarnya merupakan suatu kegiatan operasional agar tindakannya masuk pada pengertian penelitian yang sebenarnya. (Subagyo, 2015:37). Dalam penelitian kualitatif pada kesempatan ini, peneliti menggunakan beberapa teknik pengumpulan data, antara lain:

\section{Teknik Observasi}

Observasi adalah suatu kegiatan mengamati, meneliti, merekam secara tersusun sesuai rancangan yang telah ditetapkan. Observasi ialah tahapan proses yang lengkap dan susunan didalamnya terdapat proses biologis dan psikologis pendapat ini menurut Hadi dalam Sugiyono (2017:145). Ada 2 hal yang penting yaitu proses pengamatan dan ingatan. Sedangkan menurut Bungin (2012:138) Observasi adalah apa yang sebenarnya dilakukan orang, sangat berbeda dengan apa yang dikatakan oleh orang. Ketika melakukan observasi yang melibatkan orang banyak diperlukan alat bantu untuk merekam, namun ketika observasi hanya kepada individu hal tersebut tidak dilakukan tidak masalah.

Dalam observasi kali ini, peneliti memiliki pedoman untuk melakukan proses mengamati dengan seksama segala sesuatu yang terjadi di lapangan. Teknik ini digunakan untuk mendapatkan data secara lengkap tentang Peningkatan Kemampuan Kognitif Anak Usia 4-5 Tahun Melalui APE KETNI SERU di RA Al Islam 3 Gebang Tahun Pelajaran 2019/2020, keadaan guru, dan sarana prasarana.

\section{Teknik Wawancara}

Menurut Bungin (2012:155) wawancara adalah proses percakapan dengan maksud untuk mengontruksi mengenai orang, kejadian, kegiatan, organisasi, motivasi, perasaan yang dilakukan dua puhak yaitu pewawancara (interviewer) yang mengajukan pertanyaan dengan orang yang diwawancarai (interviewee). Sedangkan menurut Subagyo, (2015:39) wawancara yaitu suatu kegiatan dilakukan untuk mendapatkan informasi secara langsung dengan mengungkapkan pertanyaanpertanyaan pada para responden. Pada saat melakukan observasi, tentuny ada beberapa hal yang tidak ditemukan oleh peneliti. Oleh karena itu peneliti menggunakan teknik wawancara untuk melengkapi informasi yang 
ingin didapatkan. Diantaranya untuk mengetahui sarana prasarana, jumlah guru, jumlah pendidik dan lain-lain. Adapun yang diwawancarai adalah kepala sekolah dan guru kelas A2 di RA Al Islam 3 Gebang.

\section{Teknik Dokumentasi}

Teknik ini menggunakan alat bantu berupa kamera yang digunakan untuk merekam percakapan, memotret beberapa kejadian yang diperlukan dan beberapa catatan yang telah lampau atau yang sedang terjadi, akan terjadi yang diperlukan oleh peneliti (Bungin, 2012:142). Teknik ini digunakan untuk memperoleh data yang berkaitan dengan berbagai kegiatan yang mendukung penggunaan APE KETNI SERU dalam meningkatkan membilang benda 1-10 anak. Melalui teknik ini, beberapa hal yang dikumpulkan adalah foto-foto, RPPH, dan dokumen hasil evaluasi anak.

\section{Validitas Data}

Untuk menguji keabsahan data, peneltiti menggunakan uji kreabilitas, sedangkan tekniknya menggunakan teknik trianggulasi. Hal ini dilakukan agar hasil dari penelitian sesuai dengan kenyataan dilapangan, sehingga hasil penelitian benarbenar sesuai dengan kenyataan di lapangan. Tri anggulasi yaitu teknik untuk mencocokkan data yang didapat peneliti dengan data tambahan yang diperoleh peneliti. Sehingga keabsahan penelitian benar-benar sesuai keadaan dilapangan (Maleong, 2008:330-331). Teknik ini mencocokan data yang dimiliki dengan data lain, contohnya data pada ssaat wawancara dan data dokumentasi yang dimiliki oleh peneliti.

\section{Teknik Analisis Data}

Setelah data serta keterangan penelitian telah terkumpul, peneliti akan menganalisis hasil penemuannya dengan proses kualitatif. Artinya, peneliti akan menjabarkan lebih luas hasil penelitiannya dalam bentuk deskripsi. Sehingga diharapkan dapat dimengerti oleh pembaca.

Suatu upaya untuk menjabarkan suatu permasalahan agar jelas mana saja bagian dari permasalahn tersebut sehingga menjadi jelas batasannya permasalahan yang seeding dikaji , pendapat analisis data ini menurut Djam'an (2014:200. Sedangkan menurut Bogdan dan Biklen dalam Imam Gunawan (2014:210), menyatakan bahwa analisis data adalah proses pencarian dan pengaturan secara sistematik hasil wawancara, catatan- catatan, bahanbahan yang dikumpulkan untuk meningkatkan pemahaman terhadap segala sesuatu yang dikumpulkan dan memungkinkan menyajikan apa yang ditemukan.

Dalam hal ini analisis data yang peneliti gunakan adalah analisis interaktif. Yang terdiri dari tiga komponen, yakni reduksi data,penyajian data, dan penarikan kesimpulan. Miles dan Huberman (1992:16) menjelaskan ketiga langkah analisis interaktif tersebut antara lain yaitu:

\section{Reduksi Data}

Reduksi data merupakan suatu tahapan berupa pemilihan, pemusatan perhatian pada pengabstrakan, penyederhanaan, dan transformasi data "kasar" yang muncul. Reduksi data ini berlangsung secara terus menerus selama proyek yang berorientasi kualitatif berlangsung. Selama proses mengumpulkan data berjalan, terjadilah tahapan reduksi selanjutnya (membuat ringkasan, mengode, menelusur tema, membuat gugus-gugus, membuat partisi, dan menulis memo). Reduksi data ini bahkan berjalan hingga setelah penelitian dilapangan berakhir dan laporan akhir lengkap tersusun. (Andi, 2014:242)

Peneliti melakukan pengumpulan data dengan wawancara, observasi, dan dokumentasi tentang implementasi penggunaan Alat Permainan Edukatif (APE) dalam mengembangkan kemampuan membilang benda anak usia 4-5 tahun di RA Al Islam 3 Gebang. Peneliti merangkum, memilih hal-hal yang pokok seperti pelaksanaan penggunaan APE KETNI SERU, Metode yang digunakan, dan lainnya.

\section{Penyajian Data}

Peneliti jika sudah mengumpulkan data dari beberapa sumber dan fakta di lapanagan selanjutnya akan menarik kesimpulan dari apa yang ditelitinya. Dengan demikian pembaca akan mengerti apa yang sedang terjadi 
dilapanagan dan solusi apa yang ditawarkan oleh peneliti. Penelitian ini menyajikan datanya dengan uraian singkat mengenai implementasi penggunaan Alat Permainan Edukatif (APE) untuk mengembangkan kemampuan membilang benda 1-10 anak usia 4-5 tahun di RA Al Islam 3 Gebang. Serta dapat diselingi dengan gambar, tabel, dan lainlain disesuaikan dengan jenis data yang terkumpul.

\section{Penarikan Kesimpulan}

Pengambilan kesimpulan dilakukan setelah melalui tahap reduksi data dan juga penentuan kesimpulan yang tepat. Penarikan kesimpulan merupakan bagian penting dan dilakukan dalam analisis data kualitatif. Sejak pertama kali peneliti mendapatkan informasi, peneliti berusaha mencari data-data yang telh diperoleh, selanjutnya yang diperlukan dan tidak diperlukan dipilah, selanjutnya menyusun jaringan kerja yang berhubungan dengan implementasi penggunaan APE KETNI SERU dalam meningkatkan kemampuan membilang benda 1-10 anak usia 4-5 tahun di RA Al Islam 3 Gebang. Setelah mendapatkan hasilnya, peneliti menyajikan hasil penelitiannya dalam bentuk deskripsi. Hasil penelitian yang telah disimpulkan, hendaknya dapat diuji kebenarannya.

\section{HASIL PENELITIAN dan PEMBAHASAN Deskripsi Permasalahan Penelitian Kemampuan Kognitif khususnya membilang angka 1-10 pada Anak Usia 4-5 tahun}

Berdasarkan hasil wawancara, observasi dan dokumentasi mengenai kemampuan Kognitif khususnya membilang benda 1-10 pada Anak Usia 4-5 tahun di RA Al Islam 3 Gebang ini dapat dilihat bahwa guru sudah mencoba berusaha maksimal dalam mengoptimalkan perkembangan aspek kognitif, guru juga sudah memahami apa tujuan dari pengembangan kemampuan kognitif anak khususnya yaitu anak bisa membilang banyak benda satu sampai sepuluh. Namun, guru masih belum sempat mempraktekkan ilmu yang di dapat saat mengikuti workshop maupun seminar yang pernah di ikuti. Sehingga hasilnya anak sering bosan mengikuti pembelajaran dan belum mencapai standar penilaian yang telah di tetapkan.

Penggunaan APE untuk Membilang benda di RA Al Islam 3 Gebang

Dari hasil wawancara, diambil kesimpulan bahwa APE atau media yang digunakan saat mengajar di RA Al Islam 3 Gebang masih terbatas. Hal ini dikarenakan keterbatasan tempat penyimpanan APE dan juga kreatifitas guru dalam pembelajaran mengenal angka langsung menggunakan media realia.

Temuan Studi yang Dikaitkan dengan Teori

Peneliti telah mengkaji permasalahan penelitian yang terkait dengan Efektifitas Penggunaan APE KETNI SERU (BASKET MINI SERBA GUNA) untuk Meningkatkan Kemampuan membilang benda 1-10 pada Anak Usia 4-5 Tahun di RA Al Islam 3 Gebang Surakarta. Dari permasalahan diatas diambil kesimpulan bahwa anak bosan dalam pembelajaran membilang benda dikarenakan APE atau media yang digunakan guru monoton. Oleh sebab itu anak kemampuan anak dalam membilang benda belum sesuai standar yang ditetapkan. Selain itu ruangan di RA Al Islam 3 Gebang sangat terbatas sehingga kesulitan dalam hal menyimpan APE dan media pembelajaran. Oleh sebab itu maka peneliti yang sekaligus salah satu guru di RA Al Islam 3 Gebang membuat APE yang terbuat dari barang bekas untuk digunakan di RA Al Islam 3 Gebang. APE KETNI SERU (BASKET MINI SERBAGUNA) rangka utamanya menggunakan kardus bekas lemari es, berukuran 120 × 52 × $53 \mathrm{~cm}$. Meskipun peneliti menggunakan kardus berukuran besar, namun setelah digunakan APE ini bisa dilipat dan diselipkan disela sela lemari. Sehingga tidak memakan tempat yang banyak dalam penyimpanannya.

APE KETNI SERU (BAKSET MINI SERBAGUNA) sebenarnya bisa digunakan untuk mengembangkan aspek perkembangan yang selain kognitif, dengan kata lain APE ini sebenarnya multifungsi. Hanya saja pada penelitian ini yang diteliti dengan seksama 
adalah pada aspek kognitif terutama dalam membilang benda. Bahan yang digunakan pun mudah didapat di sekitar kita, dan tidak mahal. Selain itu APE ini aman digunakan oleh anak karena tidak terdapat bahan bahan yang berbahaya. Hal ini sesuai dengan pendapat yang dikemukakan oleh Wiyani dan Barnawi (2014: 150-151).

Pada sisi utama digunakan untuk APE Bola Basket Mini, membuat tiruan ring basket yang akan digunakan untuk memasukkan bola kedalam keranjang seperti bermain basket. Namun, bola yang dimasukkan harus seusai jumlah angka yang tertera. Pada bagian depan bawah digunakan untuk APE pasang tutup botol. Anak menempelkan tutup botol yang sudah ada angkanya. Menempelkannya sesuai posisi yang tertera di samping APE. Pada sisi kiri digunakan untuk APE menempelkan bola. Menempel bola harus sesuai jumlah dan warna pada perintah yang tertera. Pada sisi kanan digunakan untuk APE hitung jari dan hitung manik manik. Anak menghitung jumlah jari dan juga jumlah manik manik yang tersedia. Untuk setiap elemen yang terdapat pada APE KETNI SERU bisa diganti sesuai dengan tema. Proses pembelajaran menggunakan APE KETNI SERU (BASKET MINI SERBAGUNA) dengan melakukan langkah langkah sebagai berikut :

\section{Perencanaan}

Langkah perencanaan ini berdasarkan pada media pembelajaran seperti apa yang akan digunakan pada saat pembelajaran. Guru hendaknya mempersiapkan media pembelajaran yang sesuai dengan pembelajaran ayang akan disampaikan, selain itu media pembelajaran yang akan digunakan seharusnya mampu mengembangkan perkembangan anak dengan maksimal. Menurut Nana, dkk(2015:214-217), persiapan berarti kegiatan dari seorang pendidik yang akan mengajar dalam menyiapkan segala kelengkapan pembelajaran. Mulai dari RPPM, RPPH dan media pembelajaran yang akan digunakan.

\section{Pelaksanaan}

Pelaksanaan penggunaan APE di RA Al Islam 3 Gebang ini dapat dilihat bahwa anak menjadi lebih antusias dan senang belajar membilang benda dengan menggunakan APE KETNI SERU. Anak bisa belajar sambil bergerak. Tidak hanya duduk diam saja mendengarkan guru menjelaskan pembelajaran. Anak menjadi tidak bosan, bahkan berebut ingin mencobanya. APE KETNI SERU memberikan pengalaman belajar yang baru bagi anak. Pembelajaran yang menyenangkan tentunya. Hal tersebut sesuai dengan tujuan anak bermain menurut Syamsuardi (2012: 62) : 1) Mendapatkan kesempatan dalam mengembangkan potensi yang dimiliki oleh anak.2) Dengan sendirinya anak akan memahami kekuatan, kelemahan, kemampuan, kebutuhan dan minat dirinya.3) Memberi kesempatan pada anak dalam mengembangkan potensi dan aspek yang ada pada anak, baik bahasa dan perilaku (psikososial serta emosional), fisik dan intelektual.4) Seluruh aspek panca indra anak terlatih dengan baik, karena seringnya digunakan.5) Memotivasi anak agar mengetahui sesuatu lebih jauh lagi secara alamiah.

Ismail (2009:138-139) mengemukakan fungsi dari APE sebagai berikut: 1)Pemberian pembelajaran melalui proses belajar dan bermain. 2)Merangsang untuk mengembangkan daya cipta, daya pikir dan bahasa. 3)Mengatur lingkungan bermain yang aman, nyaman dan menyenangkan. 4)Kualitas pembelajaran anak menjadi meningkat.

\section{Penilaian}

Peneliti memperoleh fakta bagaimana sikap seorang guru kelas menghadapi anak yang kesulitan menerima pembelajaran, yaitu Ibu lestari memberikan perhatian kepada anak pada saat pembelajaran, terbukti dengan adanya peristiwa ibu Lestari membimbing dan memberikan motivasi kepada anak pada saat anak masih keliru membilang jumlah benda. Ibu Lestari melakukan hal tersebut dengan tujuan agar kemampuan kognitif anak berkembang. Setelah melalui proses perencanaan lalu proses pelaksanaan dan yang terakhir yang dilakukan adalah proses penilaian. Pada proses penilaian ini baru bisa diambil kesimpulan, apakah anak didik sudah 
berkembang optimal atau belum dalam bidang perkembangan kognitif khuususnya dalam membilang benda. Peneliti memperoleh hasil dari wawancara, observasi dan dokumentasi yang dilakukan pada tahapan proses penilaian dan hasil tersebut dapat disimpulkan bahwa penilaian dilakukan saat pembelajaran berlangsung namun dalam bentuk sederhana, setelah itu baru direkap kedalam penilaian harian.

Hal temuan diatas sesuai dengan pendapat dari Nana, dkk (2015:214-217), pada tahap proses penilaian dilakukan untuk mengetahui sejauh mana efektifitas pembelajaran yang disampaikan. Pembelajaran diterima anak atau tidak. Perkembangan anak menjadi bertambah atau tidak. Semua terlihat jelas didalam tahapan ini. Jika hasil penilaian masih belum sesuai standar yang ditetapkan maka guru harus melakukan instropeksi di bagian langkah mana yang masih harus diperbaiki.

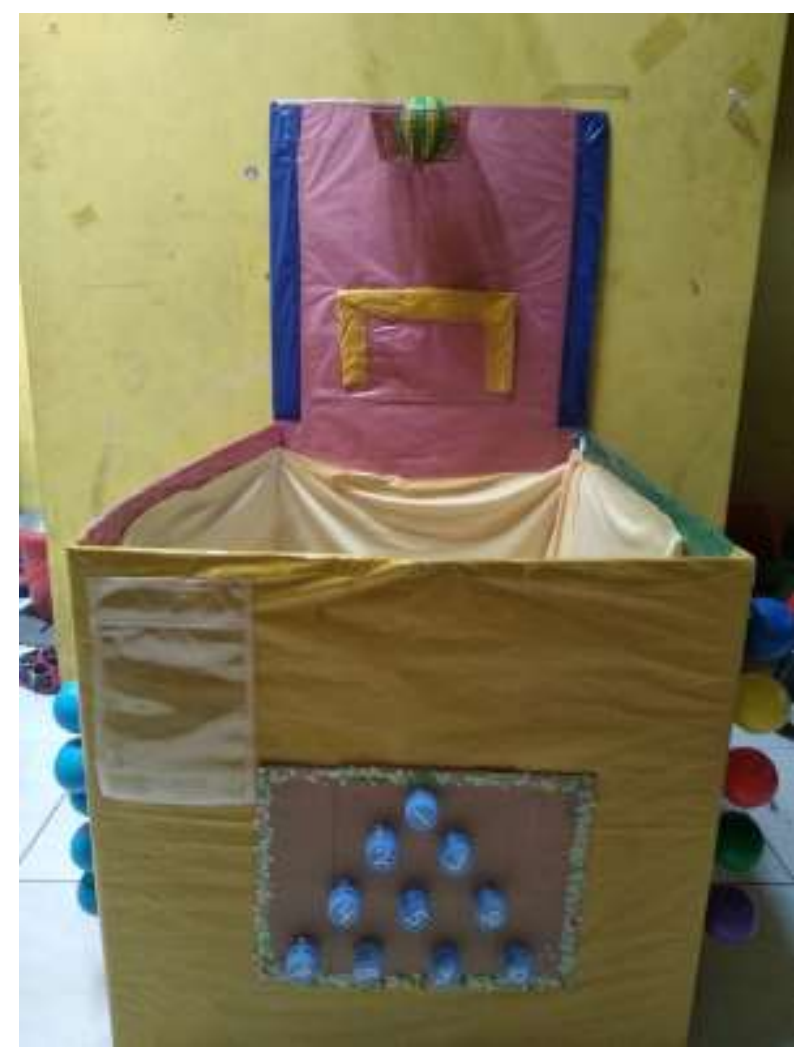

Gambar 1. APE KETNI SERU

\section{SIMPULAN}

Berdasarkan penelitian yang telah dilakukan mengenai dengan Efektifitas Penggunaan APE KETNI SERU (BASKET MINI SERBA GUNA) untuk Meningkatkan Kemampuan membilang benda 1-10 pada Anak Usia 4-5 Tahun di RA Al Islam 3 Gebang Surakarta, dapat disimpulkan bahwa :

1. Langkah perencanaan ini memilih media pembelajaran yang akan digunakan. Selanjutnya guru mempersiapkan media yang akan digunakan, selain itu media yang digunakan hendaklah bermanfaat dan dapat mengembangkan kemampuan pada anak. Salah satunya yaitu APE KETNI SERU.

2. Langkah pelaksanaan penggunaan APE di RA Al Islam 3 Gebang ini dapat dilihat bahwa anak menjadi lebih antusias dan senang belajar membilang benda dengan menggunakan APE KETNI SERU. Anak bisa belajar sambil bergerak. Tidak hanya duduk diam saja mendengarkan guru menjelaskan pembelajaran. Anak menjadi tidak bosan, bahkan berebut ingin mencobanya. Melalui APE KETNI SERU ini, anak belajar dengan suasana yang disenangi anak yaitu belajar sambil bermain.

3. Langkah penilaian, penilaian dilakukan saat pembelajaran berlangsung namun dalam bentuk sederhana, setelah itu baru direkap kedalam penilaian harian. Dari proses penilaian ini baru bisa diambil kesimpulan, apakah anak didik sudah berkembang optimal atau belum dalam bidang perkembangan kognitif khuususnya dalam membilang benda. Jika hasil penilaian masih belum sesuai standar yang ditetapkan maka guru harus melakukan instropeksi di bagian langkah mana yang masih harus diperbaiki. Pada penilaian dengan indicator yang sama sebelum menggunakan APE KETNI SERU, peneliti mendapat hasil 2 anak mendapatkan nilai Mulai Berkembang. Setelah menggunakan APE KETNI SERU, 2 anak tersebut mendapatkan nilai Berkembang Sesuai Harapan.

Dari keseluruhan langkah-langkah yang dilalui peneliti, diambil kesimpulan bahwa APE KETNI SERU (BASKET MINI SERBAGUNA) efektif untuk meningkatkan 
kemampuan membilang benda 1-10 pada anak usia 4-5 tahun.

\section{DAFTAR PUSTAKA}

Aisyah, Siti. 2014. Perkembangan dan Konsep Dasar Pengembangan Anak Usia Dini. Tanggerang Selatan: Universitas Terbuka

Andi, Prastowo. 2014. Metode Penelitian Kualitatif dalam Perspektif Rancangan Penelitian. Jogjakarta: Ar-Ruzz Media

Anisatul Khoiriyyah. 2018. Peningkatan Kemampuan Mengenal Angka Melalui Penggunaan Kartu Angka pada anak TK Kelompok A. Jurnal Pendidikan Anak Usia Dini 2 (7). (http://journal.student.uny.ac.id/ojs/i ndex.php/pgpaud/article/download/1 0717/10271) diakses 6 Januari 2020

Bungin, Burhan. 2012. Metodologi Penelitian Kualitatif. Jakarta: PT Raja Grafindo: Persada.

Djam'an Satoni \& Aan Komariah. 2014. Metodologi Penelitian Kualitatif. Bandung: Alfabeta.

Fikriyati, Mirroh. 2013. Perkembangan Anak Usia Emas (Golden Age). Yogyakarta: Laras Media Prima

Imam, Gunawan. 2014. Metodologi Penelitian Kualitatif: Teori dan Praktik. Jakarta: PT Bumi Aksara.

Ismail, Andang. 2009. Education Games. Yogyakarta: Pro-U Media

Johni Dimyati. 2013. Metodologi Penelitian Pendidikan dan Aplikasinya pada Pendidikan Anak Usia Dini. Jakarta: Kencana Prenada Media Group

J. Moelong Lexy. 2011. Metodologi Penelitian Kualitatif. Bandung: PT. Remaja Rosda Karya

Laila, Khoiris. 2009. Makalah APE. (http:/lailakhoiris.wordpress.com/ma kalah-ape/, diaskses pada 2 Nopember 2019)

Linda Yulianti, dkk. Peningkatan Pengenalan Konsep Bilangan Melalui Permainan Angka Pada Anak Usia 4-5 Tahun Di PAUD Siratul Jannah.2014. Jurnal
Pendidikan Guru PAUD S-1 3(8) (http://jurnal.untan.ac.id/index.php/jp dpb/article/view/6084/6960) diakses 6 Januari 2020

Mansur. 2011. Pendidikan Anak Usia Dini Dalam Islam. Yogyakarta: Pustaka Pelajar

Masitoh. 2012. Strategi Pembelajaran TK. Tanggerang Selatan: Universitas Terbuka

Menteri Pendidikan dan Kebudayaan Republik Indonesia. 2014. Peraturan Menteri Pendidikan Dan Kebudayaan Republik Indonesia Nomor 137 Tahun 2014 Tentang Standar Nasional Pendidikan Anak Usia Dini. Jakarta: Kemendiknas

Miles dan Huberman. 1992. Qualitative Data Analysis. Terjemahan oleh Tjetjep Rohmadi. Jakarta: Universitas Indonesia Press

Mujib Fathul dan Nailur Rahmawati, 2013. Metode Permainan-Permainan Edukatif dalam Belajar Bahasa Arab. Jogjakarta: Diva Press.

Mulyasa, 2014. Manajemen PAUD. Bandung:

PT Remaja RosdaKarya

Nasution, S. 1984. Berbagai Pendekatan dalam Proses Belajar dan Mengajar. Jakarta: Bima Aksara

Novan Ardy Wiyana, dkk. 2014. Format PAUD. Jogjakarta: Ar-Ruzz Media.

Nurani S, Yuliani. 2007. Metode Pengembangan Kognitif. Jakarta: Universitas Terbuka

Patmonodewo, Soemarti. 2008. Pendidikan Anak Prasekolah. Jakarta: Rineka Cipta

Rolina, Nolvan. 2012. Alat Permainan Edukatif untuk Anak Usia Dini. Yogyakarta: Penerbit Ombak

Subagyo, Joko. 2015. Metodologi Penelitian dalam Teori dan Praktik. Jakarta: PT Rineka Cipta.

Sugiyono. 2017. Metode Penelitian Kuantitatif, Kualitatif, dan $R \& D$. Bandung: Alfabeta

Sunaryo K, Wowo. 2013. Taksonomi Berpikir. Bandung: Remaja 
Rosdakarya

Susanto, Ahmad. 2011. Perkembangan Anak

Prasekolah. Jakarta: Kencana

Prenada Media Group

Suyanto, Slamet. 2005. Dasar- Dasar

Pendidikan Anak Usia Dini.

Yogyakarta: Hikayat Publishing

Syamsuardi. 2012. Penggunaan Alat

Permainan Edukatif (APE) di

Taman Kanakkanak PAUD Polewali

Kecamatan Tanete Barat Kabupaten

Bone. Jurnal Publikasi Pendidikan, (Online), (diakses 02 Nopember 2019).

Wiyani, Novan dan Barnawi. 2014. Format

PAUD. Yogyakarta: Ar-Ruzz Media

Zaman, Badru. 2014. Media dan Sumber Belajar PAUD. Banten: Universitas Terbuka. 